\title{
Trust-Driven Entrepreneurship for Community Well-Being of Refugees and Their Local Hosts
}

\author{
Zeynep Baktir, ' $\odot$ and Forrest Watson ${ }^{2} \odot$
}

\begin{abstract}
This article explores community well-being (CWB) outcomes of institutional trust (and distrust) through entrepreneurship in the context of a refugee-hosting society in Turkey. Existing studies show the positive relationship between institutional trust and quality of life (QOL) as well as entrepreneurship and $\mathrm{QOL}$ in subsistence contexts. This research, however, explores the relationship between institutional (dis)trust and entrepreneurship on a path to CWB with a special emphasis on refugee and local interactions in the marketplace. Three different paths to the QOL of refugees and/or locals are presented, but only two lead to CWB outcomes encompassing both refugees and locals. Consideration of refugees and locals as both consumers and business owners provides perspective on the interplay between social trust and institutional trust in a socio-culturally heterogeneous subsistence context. The article also discusses implications for theory and practice.
\end{abstract}

\section{Keywords}

institutional (dis)trust, entrepreneurship, quality of life, community well-being, refugees

\section{Introduction}

System-level trust is vital for community well-being (CWB) in increasingly diverse marketplaces. Communities around the world are confronted with the challenge of integrating an unprecedented number of some 70 million people who have been forced from their homes (UNHCR 2019). Distrust is natural for the refugees pushed from their homes into unfamiliar places, just as distrust is understandable for the local community that is apprehensive in receiving them. However, trust is crucial in risky and complex social environments with an uncontrollable future (Earle and Cvetkovich 1995; Ndubisi and Natarajan 2016). This research aims to answer the call for research on how trust can improve quality of life (QOL) at the system level.

Macromarketing is concerned with general societal flourishing. Macromarketers see that markets, marketing, and society are connected into a networked system (Dixon 2002). As in the ancient agora, there is an interdependence of the marketplace with other dimensions of civic life (Mittelstaedt, Kilbourne, and Mittelstaedt 2006). We expect that a well-functioning marketplace will help integrate growing and dynamic communities, lift the economic and psychological burdens from displaced people, and improve overall well-being (Ekici and Peterson 2009). At the bottom of the pyramid, exchange transactions based on values such as authentic engagement and co-creation of value can lead to fairer marketplaces and empowered consumers (Santos and Laczniak 2009).
Economic needs are some of the most pressing for displaced people. Finding employment or ways to generate income, typically in the informal sector, are critical. These families must also procure the goods needed for survival and better adaptation. While both researchers and practitioners recognize the role of businesses in subsistence marketplaces in general, there is scant research on businesses in refugee hosting communities, which constitute a substantial portion of subsistence marketplaces in many developing countries (e.g. Pralahad 2009; Viswanathan 2007). This study focuses on understanding the complexity of refugee consumers' trust and distrust in local businesses, and how this dis (trust) influences CWB through local and refugee entrepreneurship.

Trust is an important component of marketing exchanges that brings buyers and sellers together in the marketplaceessential for CWB (Fligstein and Dauter 2007; Mittelstaedt, Kilbourne, and Mittelstaedt 2006; Wilkie and Moore 1999). In their study on the relationship between consumer trust in market-related institutions and QOL of financially constrained

\footnotetext{
'Bilkent University, Ankara, Turkey

${ }^{2}$ Middle East Technical University, Ankara, Turkey
}

This research is a part of Zeynep Baktir's PhD Thesis at Bilkent University, Faculty of Business Administration.

\section{Corresponding Author:}

Zeynep Baktir, Bilkent University Management Department, Ankara, Turkey. Email: zeynep.baktir@bilkent.edu.tr 
consumers, Ekici and Peterson (2009) find that market-related trust affects QOL of the poor and the non-poor differently. More specifically, they show that consumers below the poverty line who have higher trust in market-related institutions experience higher QOL, while there is no such correlation for consumers above the poverty line.

In this study, we delineate how consumers' market-related (dis)trust, especially in businesses, influence CWB in the context of refugee hosting communities in a developing country, namely Turkey. While subsistence marketplaces and developing economies seem to be two distinct contexts, refugees who reside mostly in developing countries pursue lives in subsistence, and engage with the marketplace accordingly. Refugees shape and are shaped by the marketplace, which creates alternative routes to marketing exchanges and entrepreneurship.

Prior literature on subsistence marketplaces shows the positive relationship between entrepreneurship and QOL of the poor. For instance, Viswanathan, Sridharan, and Ritchi (2010) found that in a subsistence marketplace, individuals' self-efficacy, and thus likelihood to pursue entrepreneurial activities, and overcome the vulnerabilities related to poverty are increased through group involvement. Our study builds on this research by exploring how (dis)trust in businesses might lead to entrepreneurship, which in turn influences QOL (Ekici and Peterson 2009; Viswanathan et al. 2012).

We aim to make three main contributions through our research. First, we aim to build on the valuable research in subsistence contexts (Pralahad 2009; Viswanathan 2007) by considering trust in refugee-hosting communities where there is high tension across cultural cleavages. Deep divides in a community make it both difficult and critical to consider CWB, rather than looking at QOL measures of an individual group. Second, we build on Ekici and Peterson's (2009) finding that consumers below the poverty line with higher trust in market-related institutions experience higher QOL, and substantiate the connection between trust and entrepreneurship. Third, we consider the macro-level well-being outcomes of trust and entrepreneurship. Our unit of analysis is neither a firm or individual, nor individual trust or exchanges, but rather the marketplace and its interdependent community (Mittelstaedt, Kilbourne, and Mittelstaedt 2006). We consider how value is created at the micro, meso, and macro levels (Chandler and Vargo 2011) by applying the domains of community well-being (VanderWeele 2019).

The paper begins with a brief review of the literature on CWB, subsistence marketplaces, and social capital, followed by a review of the role of entrepreneurship and institutional trust on QOL in subsistence marketplaces. We present our findings from a four-year field study in several refugeehosting communities across Turkey. We discuss the implications for macromarketing researchers and practitioners in heterogeneous subsistence marketplaces.

\section{Community Well-being}

Community well-being (CWB) is a multidimensional consideration of a wide range of economic, social, environmental, political, and cultural factors (Sung and Phillips 2018) in a networked system, which is in keeping with the macromarketing tradition. "Community well-being centers on understanding of community and fulfilling needs and desires of its members" (Sung and Phillips 2018, p. 64).

In this paper, by QOL we refer to a focus on the subjective well-being of individuals (for a review, see Sirgy et al. (2006)). But in keeping with the distinction made by Sirgy (2011), our aim is to look beyond individual-level QOL. "The good society is more than the sum of the happiness of its citizens" (Sirgy 2011, p. 331). We therefore consider the QOL of individuals, but our aim is to evaluate the higher-level CWB.

We follow in the tradition of Sirgy et al. (2010) and others in focusing more on the subjective aspects of CWB, relying on the individuals' assessment of the overall well-being and perceived cultural value within the community (Sung and Phillips 2018). More specifically, we will consider subjective CWB in the domains of flourishing individuals, good relationships, proficient leadership, healthy practices, satisfying community, and strong mission (VanderWeele 2019).

CWB is a particularly desirable outcome when considering societal flourishing that spans ethnic differences in a contentious community. Trust becomes especially important in complex social environments where people must act in the face of risk and an uncertain future (Earle and Cvetkovich 1995; Ndubisi and Natarajan 2016) - just the kind of situation resulting from a massive influx of refugees into a community. CWB has been considered for refugees and local communities (Callamard 1994; Meyer et al. 2019; Whitaker 2002), but this study will focus on trust and entrepreneurial activity.

In this research, we are interested in system-level wellbeing, where trust leads to CWB through entrepreneurial activity. Because the concept of CWB is dependent on who is asked (Sung and Phillips 2018), we considered both locals' and refugees' perception of CWB. We want to explore whether (dis)trust of refugees in local businesses may lead to increased refugee and/or local entrepreneurship in a way that improves the well-being of the entire community. In other words, we do not want to see whether entrepreneurship can improve a single family or even ethnic group, but lead to improved system-level CWB (Sung and Phillips 2018; VanderWeele 2019) for a diverse and dynamic community.

\section{Subsistence Marketplaces}

Subsistence refers to the hardship individuals, households, and communities go through to meet basic needs that arise and evolve over time. Subsistence includes "the entire range of low incomefrom abject poverty on the one hand to being at the other end of low income." (Viswanathan 2017, p. 1576). Literature suggests using local definitions and relative income within the range of low income for the operationalization of subsistence.

Subsistence marketplaces consist of individuals, communities, consumers, and entrepreneurs who live at the lower end of the income bracket, and struggle to make ends meet (Viswanathan and Venugopal 2015). Past research explored a wide 
range of people from the homeless, refugees in settlements, isolated tribal communities and interior villages to urban low-income communities in emerging countries as subsistence contexts (Viswanathan 2017, Rosa and Viswanathan 2007). While subsistence communities and marketplaces are mostly in developing economies and regions, they also exist alongside more affluent communities in developed countries (Viswanathan and Venugopal 2015; Viswanathan, Rosa, and Harris 2005).

Literature on subsistence marketplaces focuses on daily economic exchanges among consumers, entrepreneurs, and markets in resource-poor contexts in an attempt to understand the dynamics of marketplace interactions of the poor (e.g.Viswanathan, Rosa, and Ruth 2010).

Despite the state of being resource-poor, the network-rich nature of some subsistence marketplaces can help consumers cope with the constraints of subsistence living (Viswanathan and Sridharan 2009). For instance, in his study on the marketplace interactions of consumers and small business owners in a subsistence context in India, Viswanathan (2007) shows that one-to-one relationships between buyers and sellers, which go beyond the traditional marketplace roles in advanced economies, may help both consumers and entrepreneurs cope with the challenges of economic and socio-cognitive constraints.

\section{Social Capital}

Social capital is broadly defined as an asset that derives from successful interactions in social networks (Burt 1997). However, trust is what turns social networks into sources of social capital (Woolcock 1998). Social capital is essential for marketplace interactions in subsistence contexts (Viswanathan 2007). One-to-one interactions based on trust could help build social capital among the players in the marketplace, which could contribute to the well-being of both consumers and entrepreneurs living with limited economic resources (Viswanathan and Srinidhan 2009).

In the context of refugees with both economic and sociocultural hardship, there may be various factors of (dis)trust in businesses and business-owners, both of which tend to be quite interrelated (Ruth and Hsiung 2007; Viswanathan 2007; Viswanathan, Rosa, and Ruth 2010). Such factors may foster entrepreneurial activities, and impact CWB in various ways.

Based on their research on entrepreneurship in immigrant communities in the U.S., Portes and Sensenbrenner (1993) suggested that social capital is high in communities with distinct cultural characteristics, and this may drive entrepreneurship among them (Anderson and Jack 2002). Putnam's (2000) concept of bridging (in addition to bonding) social capital is of particular importance to a diverse social context like a refugeehosting community.

\section{Entrepreneurship and QOL}

Entrepreneurship and consumption are highly intertwined in subsistence marketplaces of a developing economy since many individuals play the role of both buyers and sellers as they try to make a living through their micro-enterprises (Viswanathan 2007; Viswanathan, Rosa, and Ruth 2010). This situation makes trust in businesses highly linked to personal ties with business-owners in most refugee-hosting communities. Viswanathan (2007) shows that both consumers and small business owners tap into the opportunities afforded by a network-rich community in an effort to economically survive in subsistence contexts.

Entrepreneurial activities leveraging social networks can provide impoverished communities with various livelihood opportunities (Viswanathan, Rosa, and Ritchie 2010). Literature suggests that social capital can indeed contribute to sustainable economic development, and benefit the whole society (Samli 2008; Viswathan et al. 2012). Samli's (2008) research specifically highlights the crucial role of entrepreneurship on economic development, and thus on QOL in developing country contexts.

\section{Social Trust, Institutional Trust and QOL}

Trust enables any group to run more efficiently (Fukuyama 1995), and is a necessary condition for a market and exchange-based economy (Michalos 1990). There is a positive association between different measures of trust and subjective well-being in a society (Inglehart and Rabier 1986).

There are two main types of trust in the literature, namely social trust and institutional trust. Social trust, also known as dyadic trust, is trust in other people or in specifically identified individuals (Freitag 2003). Social trust is also a belief that one can trust strangers (Uslaner 2002). On the other hand, institutional trust, also known as holistic trust, shows the extent to which public trust institutions to fulfill their roles in a satisfactory manner (Sztompka 1999).

There are two alternative routes to institutional trust (Hudson 2006). While cultural theorists argue that institutional trust is exogenous, related to dyadic trust, and frequently learned early in life (e.g. Inglehart 1997), institutional theorists argue that it is endogenous and mostly influenced by the level of institutional performance (Hetherington 1998; Mishler and Rose 2001; North 1990).Literature points to the complementary nature of social trust and institutional trust (Hudson 2006). Social trust reduces transaction costs and drives economic growth (Putnam 1993). Institutional trust correlates with country development and citizens' well-being (Hudson 2006). Social trust and institutional trust can reinforce or undermine each other on a path to CWB.

We point to the role of the interplay between social trust and institutional trust on the formation of both refugee and local entrepreneurship in the context of a refugee-hosting community where locals and refugees of different sociocultural backgrounds engage with each other and with the marketplace. In such a context, trusting comes forward as a useful strategy that might help refugees adapt to complex social environments in the face of uncertainty and risk (Earle and Cvtkovich 1995). Trust in businesses in this context is 
heavily dependent on the business owners themselves, who tend to live together in the same community with their customers (Viswanathan et al. 2014).

With this research, we aim to shed light on how (dis)trust of refugees in local businesses is formed, and how it may possibly influence CWB through local and refugee entrepreneurship. Merging the two lines of literature on the positive relationship between entrepreneurship and well-being (e.g. Samli 2008), and institutional trust and well-being (e.g.Ekici and Peterson 2009), we will explicate various ways through which everyday interactions between refugee consumers and local business owners could increase (dis)trust in local businesses, foster entrepreneurial activities, and increase CWB.

\section{Methodology}

\section{Context of Syrian Refugees in Turkey}

There are over 3.6 million Syrian refugees registered in Turkey, 98 percent of whom live in 81 different cities across the country (UNHCR 2019). For instance, as of October 2019, Istanbul hosts the largest number of Syrian refugees with over half a million, followed by Gaziantep, a border city, with just under a half million. Overall, Syrian refugees constitute 4.5 percent of the total population in Turkey (DGMM 2019; TUIK 2019). The large numbers of Syrian refugees across Turkey necessitate consideration of different livelihood opportunities, one of which is entrepreneurship. According to a survey study on Syrian entrepreneurship and refugee start-ups, 24 percent of Syrian businesses in Turkey are founded by first-time entrepreneurs (TEPAV 2018). Syrian enterprises employ 9.4 Syrians on average (Building Markets 2017). Most Syrian-owned microenterprises in subsistence marketplaces operate in the informal sector and may affect market dynamics, and thus CWB in some diverse ways. Hence, we collected data from locals as well as refugees, and from consumers as well as business owners in an attempt to explore the lived experiences of various parties involved in marketplace interactions.

\section{Data Collection and Analysis}

The findings of this study are based on the fieldwork conducted in Ankara, Gaziantep, Istanbul, and Kayseri in Turkey from 2015 to 2019 . The project started with the active participation of the first author at some local NGOs and her initial interviews with the NGO staff, who later assisted with the recruitment and interviewing of both refugee and local participants.

Participants were recruited with a snowballing approach once initial connections were made. Data were collected through participant observation and focus groups as well as semi-structured, in-depth interviews over the course of four years. Our interviews allowed participants to share some detailed accounts of their interactions with each other and with the marketplace. Social media posts as well as newspaper and magazine articles served as practical conversation starters with both local and refugee participants.
Interviews with refugees were conducted in Arabic, Kurdish, or Turkish based on the language preference of the participants. A simultaneous translator from the refugee community at each research site assisted with the data collection and served as key informants. A total of 40 interviews were conducted with refugee participants. Interviews took place in refugees' homes, businesses, NGO offices, or public meeting places. Each interview lasted between 55 and 190 minutes. Due to the legal restrictions on tape recording of refugee participants, extensive fieldnotes were taken. The researcher and the translator of each site worked closely both during and after every site visit for the collection and analysis of data. While it was challenging to take notes during the interviews, translators who were themselves refugees from the research sites helped conversation flow, and prevented awkward moments of interruption when the researcher took notes. Fieldnotes were taken in as much detail as possible during the interviews. After spontaneous encounters with refugees during participant observation, quick notes were taken to be further developed afterwards. Fieldnotes were reviewed and discussed promptly with the translators upon data collection. The data collection resulted in about 920 pages of fieldnotes for analysis.

We also conducted interviews with 40 locals in the communities that are hosting refugees. Interviews took place at locals' homes, businesses, or public meeting places. Each interview lasted between 45 and 75 minutes. Interviews were tape recorded and transcribed for analysis.

Follow-up interviews with some local as well as refugee participants enabled member checks, and allowed us to challenge our assumptions and conclusions as researchers (Mason 2002). To help assure the validity of our conclusions, we triangulated across participants and data sources, and checked for researcher effects during our research (Miles 1994). Reflecting on data via conversations between translators and the researcher (the first author who was on site for data collection) helped us check the effects of the sites on the researcher and put our findings into perspective. Triangulation of multiple data sources such as participant observation, in-depth interviews, focus groups, and media proved to be useful to test our findings. We also searched for negative evidence of those who are skeptical about refugee involvement with entrepreneurship and CWB altogether.

In sum, we conducted 80 interviews with both refugees and locals in order to provide a balance in perspectives. In our data collection and analysis, we worked hard to fairly represent the different participants and understand their perspectives, as all are important in considering CWB. In the quotations included in the following sections, we have given extra emphasis to the refugee voice. As refugees are often marginalized in many host contexts, we wanted to enable the reader to see the tensions through refugees' eyes. Nevertheless, we have also included quotations from the locals.

Our analysis involved continuously reflecting on the data in order to identify the themes that related to refugees' trust in local businesses, local businesses' attitude toward refugees, refugee and local entrepreneurship, and CWB. We utilized 


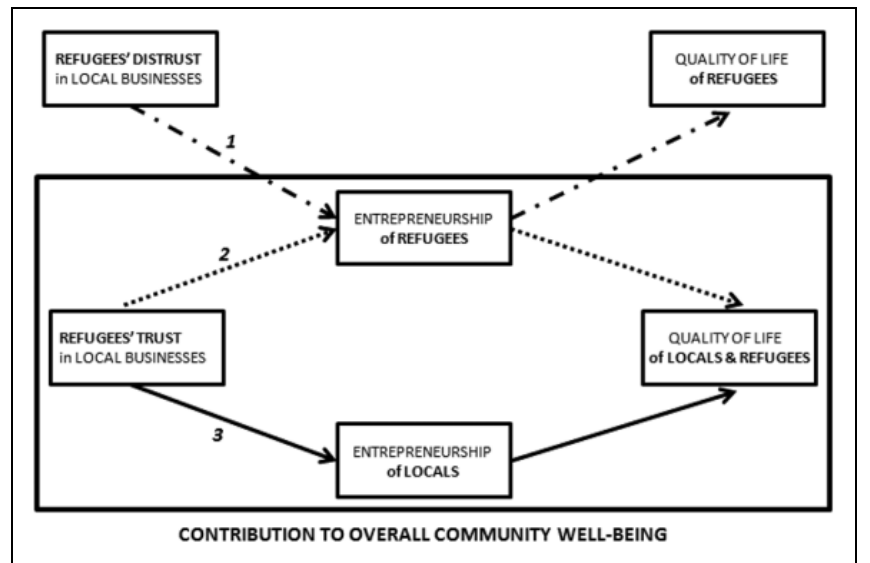

Figure I. Inductive model of trust-driven CWB through entrepreneurship.

open coding to come up with emerging and dominant themes, and axial coding to explore relationships across these themes (Miles 1994). We created analytical categories derived from data to explain different factors of (dis)trust that might lead to entrepreneurship. We analyzed CWB outcomes of increased entrepreneurship through the lens of the domains proposed by VanderWeele (2019). Based on our data analysis, we developed a conceptual model of how refugees' (dis)trust in local businesses may lead to local and/or refugee entrepreneurship, and eventually could increase CWB.

\section{Findings}

Our findings explicate multiple paths through which trust or distrust in local businesses contributes to entrepreneurial endeavors among locals and/or refugees, and eventually influence the QOL of locals and/or refugees. We introduce our emerging model in Figure 1 to provide an initial look at how CWB is related to institutional trust. The figure depicts the links between (dis)trust, entrepreneurship, and QOL. Based on our data collection and analysis, we arrived at three different paths from refugees' trust or distrust in local businesses to QOL improvements in different domains. As defined earlier, we use QOL to refer to the subjective well-being of individuals (Sirgy et al. 2006), and CWB to refer to the subjective assessment of the overall well-being and perceived cultural value within the community (Sung and Phillips 2018) across six domains (VanderWeele 2019).

Path 1 starts with refugees' distrust in local businesses, which drives refugee entrepreneurship, and can eventually increase QOL of refugees. Alternatively, path 2 and path 3 start with refugees' trust in local businesses, and lead to QOL improvements for both refugees and locals as a result of increased refugee and/or local entrepreneurship. Of the three paths, path 2 and path 3 contribute to CWB encompassing both locals and refugees, while path 1 contributes to the well-being of refugees only. What makes the outcome of path 2 and path 3 different from that of path 1 is the different ways that refugees engage in entrepreneurial activities. Partnering with local businesses, and serving both refugees and locals help refugee entrepreneurs on path 2 and path 3 contribute to CWB through increased livelihood opportunities for all.

Table 1 lists different (dis)trust factors that lead to local and/ or refugee entrepreneurship on the three paths inducted from our interviews.

In the following sections we will provide evidence and analysis for the three paths, and the specific themes for each path that emerged from the data. We conclude our findings by providing evidence of the different well-being outcomes according the domains of CWB.

\section{Path I: Distrust-driven Entrepreneurship of Refugees}

On this path, we will explain how refugee entrepreneurship increases as a result of distrust in local businesses. We will first present different factors of refugees' distrust in local business, and then explain how distrust in local businesses drives entrepreneurship among refugees. We will also provide some negative cases of how this path may not lead to QOL for locals.

Refugees' Early Negative Customer Experience with Local Businesses' Unfavorable Attitude is an important factor that determined the level of subsequent distrust refugees place in local businesses. Refugees' dissatisfaction with local businesses revolves around unequal treatment, lack of in-store care and respect, and price discrimination.

Unequal treatment and lack of in-store care and respect seem to have shaped refugees' initial distrust in local businesses as stated by a refugee consumer in the following quote:

Local shopkeepers do not treat us well in general. Just because we did not have any other options or because we did not know enough Turkish, they took advantage of us at the beginning. Some still treat us like crap, seriously. The way they speak, like cursing. As if we ask for food for free you know, like we beg. We have the money and we want to buy from them, but they do not take care of us like normal customers. We are always secondary... For instance, if Turks come in while we are shopping, they ignore us and take care of them first. They even humiliate us in front of them. Would you go to such a store again? Could you ever trust that shop keeper? Of course not. Will he give you rotten products? Will he charge you more? You never know. (Amira, refugee consumer)

Pervasive use of social media among refugees makes it easier to disseminate information of any kind including that related to their customer experience with local businesses. Many refugees were motivated to build micro-enterprises in order to serve fellow refugees because of their dissatisfaction with local businesses. The following remarks from a refugee entrepreneur illustrate how he decided to open his own little shop:

We have this Whatsapp group consisting of Syrians living around here... There I noticed that everybody was complaining about local businesses, how bad Turks treated Syrians, how they discriminated against us, sold bad stuff at much higher prices, etc. etc. I 
Table I. Factors of (Dis)trust, Entrepreneurship, and QOL.

\begin{tabular}{|c|c|c|c|}
\hline \multirow[b]{2}{*}{$\underset{\mathbb{L}}{\mathrm{I}}$} & $\begin{array}{l}\text { Refugees' Distrust in Local } \\
\text { Businesses }\end{array}$ & Entrepreneurship of Refugees & $\begin{array}{l}\text { Quality of Life } \\
\text { of Refugees }\end{array}$ \\
\hline & $\begin{array}{l}\text { Refugees' Early Negative Customer } \\
\text { Experience with Local Businesses' } \\
\text { Unfavorable Attitude }\end{array}$ & Refugees establish own micro-enterprises & $\begin{array}{l}\text { - Livelihood opportunities for refugees } \\
\text { - Lower prices for refugees } \\
\text { - Psychological well-being of refugees }\end{array}$ \\
\hline & $\begin{array}{l}\text { Refugees' Trust in Local } \\
\text { Businesses }\end{array}$ & Entrepreneurship of Refugees & Quality of Life of Locals \& Refugees \\
\hline & $\begin{array}{l}\text { Local Businesses' Procurement } \\
\text { Efforts }\end{array}$ & Refugees get into wholesale business & $\begin{array}{l}\text { - Livelihood opportunities for all } \\
\text { - Decreased resentment toward } \\
\text { refugees } \\
\text { - Psychological well-being of refugees } \\
\text { - Social cohesion }\end{array}$ \\
\hline \multirow{6}{*}{ 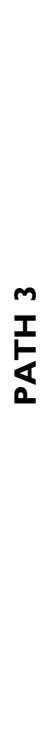 } & $\begin{array}{l}\text { Refugees' Trust in Local } \\
\text { Businesses }\end{array}$ & Entrepreneurship of Locals & Quality of Life of Locals \& Refugees \\
\hline & $\begin{array}{l}\text { Local Businesses' Good Customer } \\
\text { Service to Refugees }\end{array}$ & $\begin{array}{l}\text { Social license to serve refugees in new } \\
\text { sectors }\end{array}$ & \multirow{5}{*}{$\begin{array}{l}\text { - Livelihood opportunities for all } \\
\text { - Decreased local resentment toward } \\
\text { refugees } \\
\text { - Psychological well-being of refugees } \\
\text { - Social cohesion }\end{array}$} \\
\hline & $\begin{array}{l}\text { Local Businesses' Everyday Acts of } \\
\text { Kindness and Goodwill toward } \\
\text { Refugees }\end{array}$ & $\begin{array}{l}\text { - Social license to serve refugees in new } \\
\text { sectors } \\
\text { - Ripple effect of trust in local } \\
\text { businesses } \\
\text { - Local-refugee partnerships }\end{array}$ & \\
\hline & $\begin{array}{l}\text { Local Businesses' Acts of Trust for } \\
\text { Refugees }\end{array}$ & $\begin{array}{l}\text { - Reciprocation of trust by refugees } \\
\text { - Ripple effect of trust in local } \\
\text { businesses }\end{array}$ & \\
\hline & $\begin{array}{l}\text { Local Businesses' Sector-specific } \\
\text { Expertise }\end{array}$ & Dominance of locals in certain sectors & \\
\hline & $\begin{array}{l}\text { Local Businesses' Procurement } \\
\text { Efforts }\end{array}$ & Local-refugee partnerships & \\
\hline
\end{tabular}

saw the opportunity! There was this empty space underneath our house, and we decided to turn that into a little grocery store. (Nabil, refugee entrepreneur)

As one customer of this particular refugee business mentioned, negative customer experience of refugees with local shops caused them to feel alienated, and made it harder for them to adapt to displacement at the beginning. However, proliferation of refugee businesses over time provided refugees with some good alternatives over the local ones with which they were not satisfied:

Here I have to do the grocery shopping myself unlike in Syria. At the beginning it was a nightmare every time I went to that Turkish shop. They made me feel like trash, reminding me that I was a refugee every time I was there. From the way they looked at me and my kid to the tone of their voice... I am glad there are now many shops like this one here, of fellow Syrians, where I can shop peacefully. It is not like I am inferior. They treat me like a real customer here. I don't feel like a refugee when I come to this shop. Things are getting better now, thank God, thank God. (Fatma, refugee consumer)
The mere experience of shopping from a refugee-run business, where she is treated equally with all other customers, and not like a refugee contributed tremendously to Fatma's psychological well-being. Considering most refugees shop daily to cook for their large families, their customer experience with grocery stores, in particular, has a daily impact on their general mood and outlook toward life.

Price discrimination, which leads to distrust in local businesses encouraged some refugees to get into food-related businesses. The following quote from a refugee entrepreneur shows how price discrimination motivated his small business:

When we first came here, we hardly understood any Turkish. So, we had to rely so much on local shopkeepers in the neighborhood. Yet, they not only treated us bad but also cheated us! For instance, they sold something that was actually 1 TL for 4 TL to us!! You can't trust those people again after you notice such things. If you keep buying groceries from locals possibly at such inflated prices, you cannot feed the ten people at home. Some of us opened grocery stores just for this reason... Just so we could feed our families at reasonable prices. Thank God, I can also make a living selling food to others. (Mahdi, refugee entrepreneur) 
Such entrepreneurial endeavors not only helped refugees access to lower prices, but also provided them with some livelihood opportunities. As explained, we found there is a path from refugees' distrust in local businesses to increased refugee entrepreneurship, but it is in the next two paths that trust-driven entrepreneurship leads to CWB.

It is important to note that refugee entrepreneurship at times led to frictions in the community. For instance, lower prices offered by some refugee businesses thanks to their tax advantage and low rental cost shook the market dynamics, and led to lost customers for many local businesses in the community as mentioned below by a local business-owner:

Can you imagine? Guy comes here, to my neighborhood, starts a quick business out of nothing by bringing in cheap fruits and vegetables, and you just keep watching how your old time customers, even friends of ages in the neighborhood, go shop there in dirty Syrian shops... Believe me no Turk goes eats at their restaurant because they don't get inspected and all just like they don't pay taxes, either. They are mostly unregistered you know. But who cares where you buy apples and pears from? Does it matter? They are the same apples and pears. They all come from the same wholesale place. But these guys (Syrian shops) can sell them for cheaper, a lot cheaper. No tax, of course. No rental cost either most of the time. They just open a shop at one little corner. Can we do that? Inspectors show up next day. That little corner is packed whole day. I can't believe even my old customers who bitch about them (Syrians) so bad still go shop from their shops, and ditch me like this ... They can't even look at my face with those shopping bags on their way home. Believe me, there is not much I can do. I lost business like $50 \%$ at least, at least, compared to last year when that shop (Syrian) was not there. But there is no way I can compete with their prices... I am mad, so mad! (Necati, local business owner)

While low prices afforded by refugee businesses were wellreceived by local consumers, who mostly work in informal sector with less than minimum wage, they were aware and concerned about the sensitivities in the community caused by their shopping choices as a local consumer points out below:

I know Turkish shops here are not very fond of the situation, and honestly, I understand them. But what would you do if you were me? I have 2 kids going to school. Everyday they need something else. I have to pay rent and feed my family, too. My husband makes like $2000 \mathrm{TL}$ per month. Of course I will go for the cheaper option if I can buy something at a lower price! Especially if it is fruits and vegetables you know. Syrians sell them for much cheaper, and tomato is the same tomato everywhere. And let me tell you this... Theirs are even fresher because they bring in stuff daily most of the time and sell quick. But I know Brother Mahmut (a Turkish grocery store) gets upset when he sees us shopping else where, I mean the Syrian shops. I feel ashamed, too. So, do my best not to get caught by him (Brother Mahmut) or his wife while shopping from that Syrian grocery store. Unfortunately not always possible though. We were like family before, but now ... That breaks my heart. I understand him. But I have to do what I have to do. (Nimet, local consumer)
As Nimet puts, relations in the community may get hurt due to the competitive advantage of some refugee businesses. Local consumers are willing to take advantage of the lower prices afforded by refugee businesses even at the cost of their long term relationships in the community. But interestingly, local consumers' preference for refugee vendors is mostly limited to fruits and vegetables category even though refugees run different types of food businesses. As another local consumer brings up below, hygiene is a major concern among local consumers, which may keep them away from refugee businesses in general:

Of course I buy my fruits and vegetables from them (Syrians). I don't know how but they can sell everything for so cheap. There is a huge price difference between Syrian shops and Turkish shops. Honestly, I am not a big fan of them but why to pay more for the same cucumber you know? But listen... I never ever go buy ground meat or poultry and stuff like that from them (Syrians). For fruits and vegetables, you're safe. Everybody brings them from the same place. But, I never eat at their restaurants, or go buy those desserts regardless of how fancy they look... Do you want to get poisoned or what? We see how dirty their shops look from the outside. I can't imagine how they are inside! The kitchens you know. They are not subject to much health inspection, as far as I heard. So, you've got to be careful. Stay away from nasty Syrian shops. (Sait, local consumer)

While businesses have the potential to bridge the distance between the two communities, they can also be the source of labeling and further prejudice toward refugees. Thus, formal registration of refugee businesses and proper inspections are important not only for establishing a level playing ground for both local and refugee businesses, but also for addressing the various consumer health concerns that may form the basis of a negative attitude toward refugee businesses in certain categories.

\section{Path 2: Trust-driven Entrepreneurship of Refugees}

On this path, we will explain how refugee entrepreneurship increases as a result of trust in local businesses. We will first introduce different reasons for refugees' trust in local businesses, and then explicate how trust in local businesses drives entrepreneurship among refugees.

Local Businesses' Procurement Efforts for some ethnic products, which are highly demanded by refugees are perceived as a display of respect for refugees. Through special procurement efforts, local businesses can gain refugees' trust, and thus business. One refugee consumer explains how she trusts a local business due to its product offerings:

There is this Turkish store which sells clothes, etc. The owner does not only treat us well but also tries to cater to our taste. $\mathrm{He}$ is a Turkish guy but brings in clothes that Turkish women do not wear at all. Also the cosmetics he brings in from Gaziantep ... We used to buy those from Gaziantep before war. Now, he brings those here just for us even though Turkish women have no idea what they are 
for. Products for skin lightening, eye-shaping, etc. When they (Turkish shops) make an effort to carry the products that we are used to, I really appreciate that and try to shop from those Turks more often. When they make such an effort to bring in the products specific to $u s$, our culture, it is kind of a respect to us. If a business owner bothers to find and sell your things, that means he cares about you, doesn't it? Then you can trust such a person. (Rima, refugee consumer)

Refugees' increased trust in local businesses in the marketplace encourages more local entrepreneurs to serve the refugee market by enhancing their product assortments accordingly. But local entrepreneurs can tap into new businesses that cater to the different consumption needs of refugees only if they have access to the supply chain networks of relevant ethnic products. This necessity creates an entrepreneurial opportunity for some refugees in wholesale business as the following quote from a refugee entrepreneur illustrates:

At the beginning Turks were not that willing to sell stuff to Syrians. Syrians were not happy with their service, either. They treated Syrians not so well. But we got so crowded here over time that Turks had no choice but acknowledged us as customers. How will you survive otherwise? As Syrians started to shop from some Turks, some of them even wanted to sell products specific to Syrians. But most didn't know how to supply such products. I helped some of my Turkish neighbors here. I have many contacts in Gaziantep. Know some Syrian manufacturers in person. I could get some good prices. Everybody was happy. So I said "Why not do this for a living? Let me get into wholesale business and make some money out of this!" (Maher, refugee entrepreneur)

Maher's comments above illustrate how local businesses' increased willingness to supply products specific to the refugee community proved to be a viable entrepreneurship opportunity for some refugees. In this path we have shown how refugees' trust in local businesses can increase refugee entrepreneurship, and in the third path we will detail how it can also improve local entrepreneurship, the other component toward CWB.

\section{Path 3: Trust-driven Entrepreneurship of Locals}

On this path, we will explain how local entrepreneurship increases as a result of refugees' trust in local businesses. We will start with a general misconception among local businesses regarding refugees' shopping behavior. Then we will explicate how some local businesses manage to build rapport with refugees, and thus gain their trust. Finally, we will illustrate how increased trust in local businesses drives entrepreneurship among locals.

Our interviews shed light on some unintended consequences of refugees' aforementioned shopping behavior, which is perceived by most locals as nationalism and extreme refugee solidarity against local businesses. Such an understanding causes local community's resentment of refugees as the following quote illustrates from the perspective of a refugee consumer:
They (Turkish stores) get mad saying we always shop from Syrian stores, but not from them - on purpose, with some bad intentions. Yes, some went out of business here but it is not our fault! The number of Syrians got more and more in this neighborhood, and so did the number of Syrian shops. It is true that most of us go to the shops of fellow Syrians but it is not because we want to hurt Turkish people. It is because they don't respect us at all! We shop where we are cared and respected like a normal customer. Your dignity gets hurt so much when you are treated so bad even as a customer, with your own money. Whenever I went to a Turkish shop, I felt so humiliated that I stopped buying anything from them the moment I found Syrians selling similar products. (Yara, refugee consumer)

However, local businesses, which stay close to refugees have a better understanding of refugees' shopping choices. Especially in an environment where both refugees and locals are exposed to frequent anti-refugee rhetoric fed by daily politics and media, local entrepreneurs who make an effort to build and sustain refugee consumers' trust succeed, as also exemplified by the quote from Rima on the previous path.

Good Customer Service that provides refugees with a pleasant and smooth shopping experience helps local entrepreneurs succeed in a community highly populated with refugees.

Any effort of local businesses to provide refugees with positive customer experience contributes to refugees' trust in local businesses, and drives local entrepreneurship. The following quote from a local entrepreneur illustrates how he decided to get into a new line of business when he realized the potential of the social capital he had built as a result of the positive customer experience that he diligently curated over time for refugees:

When they (refugees) first came, I had little to none Syrian customers. Then I hired a Syrian, and he helped me attract many refugee customers. We made them feel welcome here. I treated them with respect. I didn't waste any opportunity that would help me gain their trust. They have strong news network... You can't believe how they influence each other over Whatsapp ... Over time I became the go-to seller of school clothing for Syrians. But it's seasonal you know. Women's clothing, on the other hand, is yearlong and the money is there. I knew most Syrian women in the neighborhood already. So I said why not? I tried to build rapport with each and every one that visited my store in any way that I could - and I still do. Moreover, I made it easier for them to shop at my place. Tried to be more flexible with the payments. Provided them with some easy payment options. Stretched my return policy, etc. Standard things you know, but no one does them for Syrians. I did! And when I ventured into women's clothing, I had my Syrian customer base ready. Treating them well from the very beginning helped me a lot! I was already a trusted vendor for them. (Cavit, local entrepreneur)

Cavit's efforts to provide refugees with good customer service in one line of business gave him social license to operate in another line that serves some other needs of refugees. He capitalized on the trusting relationships that he had built with the refugee community. 
Refugee employment by local businesses ensures good customer service to refugees due to better communication, and thus helps refugees build trust in local businesses. It also serves as a living declaration of a favorable attitude toward refugees, and helps build rapport with the refugee community. The following quote from a refugee consumer highlights how some local entrepreneurs benefit from refugee employment in terms of gaining trust of the refugee community:

Husbands work for long hours here and we (women) need to do everything from grocery shopping to paying the bills. But we know little to no Turkish. So shopping is an issue if you have to go to a Turkish store. I avoid this if possible. But there are some shops which employ Syrians for translation. That is really helpful. You can communicate properly, and do not feel like you will be cheated or taken advantage of while shopping. Their employing a Syrian also shows Turks' willingness to serve us, the Syrians. This means we will not be discriminated against, and we will be treated with respect like a normal customer. When I am assured that I will be taken good care of while shopping, I can trust those people. (Bushra, refugee consumer)

Refugees consider the availability of a Syrian employee in a local shop as a commitment to good customer service for refugees. As a result, refugees tend to trust local businesses, which employ Syrians.

Local Businesses' Everyday Acts of Kindness and Goodwill toward Refugees increase refugees' trust in local businesses, and thus drives local entrepreneurship targeting the refugee community. Some local businesses successfully leverage everyday acts of kindness and goodwill to build trust-based business relationships with the refugee community as stated in the following quote from a local entrepreneur:

There are some basics to the success of a shopkeeper ... First and foremost, you should not fall short of keeping your customers pleased at all times. It does not matter if they are Turks or Syrians. But, you should be extra careful about the way you interact with Syrians, in particular. They are very sensitive and well-connected, too. You do something good or bad, all hear about it in a minute. Their use of social media is unbelievable. So when they come here I treat them with care, respect, and of course with a smiling face. I make them feel good here. There are days they need help with some official procedures at the municipality, etc. I don't hesitate to give them a hand. They trust me this way and keep coming. You know what... I decided to get into gold business some time ago with my refugee network in mind. They buy and sell gold a lot. And thank God they didn't think twice about gold shopping from me. Because like I said they trust me. So, I make some good money from my new gold business thanks to the Syrians here. (Naci, local entrepreneur)

Naci's efforts to connect with the refugee community by assisting them with some bureaucratic issues expands well beyond the role of a usual business owner. His efforts lead to refugees' trust in him, and thus in his business as trust in businesses and business owners tend to be highly related in subsistence contexts (e.g. Viswanathan 2007). Naci taps into new business opportunities afforded by refugees' trust in him as a result of his everyday acts of kindness and goodwill toward refugees.

Refugees' choice of local vendors is also shaped by businesses' in-kind support of fellow refugees in need. Local entrepreneurs, who comply with the expectations of Syrians in terms of everyday social responsibility practices gain trust of the refugee community, and thus their business:

In Syria, they used to sell stuff like fruits and vegetables much cheaper later toward evening hours. This way poor people could eat, too. Turks never do that... They even trash food but never sell them for cheaper! But there is this Turkish vendor Feyyaz in the neighborhood bazaar who simply gives away fruits and vegetables, which are likely to go bad next day. Syrians in need get them most, and he knows this. Syrians who heard about this started to buy from Feyyaz during the day, and those who couldn't afford got some food for free in the evening. Everybody won at the end! We Syrians buy in bulk because we have large families. So it is good for him and for us in general. His stand gets more and more crowded each time. That Turkish guy even opened his second fruit stand, for instance, thanks to Syrians! (Hafsa, refugee consumer)

Feyyaz's in-kind support of refugees in need helped him gain trust of the refugee community and encouraged refugees to shop from him. He even ventured into another fruit stand in the neighborhood bazaar, and enjoyed the benefit of increasing refugee business.

Sharing sorrow as well as joy of refugees is another way local businesses gain the trust of the refugee community. Businesses can build social capital that may translate into different business opportunities for local entrepreneurs in the larger community as the following quote from a refugee consumer exemplifies:

There is this store, which sells gas. The owner had a Syrian employee who passed away because he was sick. He (the Turkish business owner) did not open the store for 3-4 days. He wanted to mourn over the loss ... of his Syrian employee? That was very nice and thoughtful of Necati (the local business owner). He won our hearts! Everybody appreciated his behavior so much. Later we heard that Necati's brother got into dairy business. Whole neighborhood lined up once they heard the dairy guy was his brother. It is difficult to find good daily milk you know ... They do so much tricks to sell you bad quality milk these days. But we know Necati is a good guy. So, we can trust his brother, too . . . (Hamida, refugee consumer)

These comments point to the ripple effect that trust in some local businesses creates in the larger local business ecosystem. Refugees' trust in certain local businesses spreads to some other local businesses in the community, and drives local entrepreneurship.

Local Businesses' Acts of Trust for Refugees help them gain trust of the refugee community in return. Local businesses' trust in refugees is reciprocated by refugees with trust 
in local businesses, which helps local entrepreneurs build and sustain trusting business relationships with the refugee community. This way trusted local businesses spread the advantage of the bridging social capital that they build over time with refugees to some other local businesses in the community (Putnam 2000). For instance, once a local business establishes trust with refugees through constructive daily interactions in the marketplace, recommendations and referrals made by this particular business regarding some other local businesses in the community become more credible to the refugee community as the following remarks from a refugee consumer illustrate:

Sometimes you go to buy a pair of shoes for your kid, and then you really like something for yourself, too. You know you don't have the money for both, and the kid needs those shoes more than you do. When Ibrahim (local shopkeeper) notices that you are really into those shoes for yourself, he says "Take it now, you pay next week." That means a lot you know... He trusts us! There are so many other shoe shops but we go to Ibrahim's shop most of the time. If he trusts us like that, we trust him, too. I also trust him when he recommends another Turkish store. There is this new clothing place of one of his friends. I always go there when I need to shop for my husband. Because he is Ibrahim's friend, I don't think he would cheat us. (Lama, refugee consumer)

As a result, trusting acts of a local business toward refugees not only increases trust in that particular business but also trust in local businesses in general, which supports local entrepreneurship.

Local Businesses' Sector-specific Expertise also helps them gain trust of the refugee community. Such expertise provides local entrepreneurs with some competitive advantage over refugees, and thus some lucrative business opportunities. Especially big ticket items that require technical expertise, safety, durability, and long term care put local entrepreneurs ahead of refugees in the marketplace as the following quote from a refugee consumer explains:

There are things you want to buy from Turks no matter what... Like home heating systems, furniture, etc. Safety and quality matters for such things you know... You don't want your stove to explode while you are sleeping. Turks have better technical service. They also have warranty, too. Even for second-hand goods for like 3-6 months. If you buy used furniture from Syrians, for instance, it breaks down in no time. Syrian shops would not repair them or accept return / change. Turks usually do. You still want to buy second-hand furniture from Turks even if they don't repair or accept return/change. Syrians use such stuff brutally because we are so crowded you know. So, you want to go buy such stuff from shops, which have access to the Turkish secondary-market. And those are mostly Turks themselves! (Maryam, refugee consumer)

Local entrepreneurs benefit from their local ties that give them access to higher quality products and services, which help gain trust of the refugee community. Refugees' trust in local businesses in certain sectors leads to increased local entrepreneurship, and thus livelihood opportunities in such sectors.
Local Businesses' Procurement Efforts for some products specific to the refugee community pave the way to localrefugee partnerships, and creates some entrepreneurial opportunities for both locals and refugees as the following quote from a refugee entrepreneur illustrates:

Not all shops had connections like mine. So they were asking for help to supply Syrian products. Over time, some Turks wanted to sell Syrian products, too. One, which I know even offered partnership. Dursun (local business owner) had wanted to sell some Syrian products a while ago, and I had helped him supply. He carried many Syrian products that most Turkish shops never sold. Syrians around here liked and respected Dursun a lot! So, I was very pleased about his offer. We decided to get into wholesale business together. We now sell goods (specific to Syrians) to both local and refugee shops in the region. We also do retailing. Sell to both Turks and Syrians. Thank God, business is well. We employ 2 Turks, 3 Syrians. (Abbas, refugee entrepreneur)

Dursun's early procurement efforts for some ethnic products helped him build trust in the refugee community, which later turned into a fruitful partnership with a refugee business owner.

\section{Community Well-being Outcomes}

We utilized the measure of CWB proposed by VanderWeele (2019) to assess the collective well-being of locals and refugees. Our analysis has attempted to show that trust-driven entrepreneurship leads to CWB. While distrust-driven entrepreneurship of refugees improves the QOL of the refugee community in some respects, it may further segregate locals and refugees. Refugees' opting to interact within a marketplace of their own may increase the socio-cultural divide between locals and refugees, and hinder CWB. Based on our analysis, we suggest that paths 2 and 3, but not path 1 in Figure 1 contribute to CWB. VanderWeele's (2019) measure of CWB refers to six domains, namely flourishing individuals, good relationships, proficient leadership, healthy practices, satisfying community, and strong mission. We will explain the CWB outcomes of path 2 and path 3 through the filter of these six domains.

On path 2, refugees' trust in local businesses increases refugee entrepreneurship in the form of wholesale businesses. On path 3, refugees' trust in local businesses leads to the proliferation of local entrepreneurs who aim at serving the refugee market as well as refugee-local partnerships. The ripple effect created by trusted local businesses helps spread trust in the marketplace, and drives local entrepreneurship in general. Increased entrepreneurship on both path 2 and path 3 contributes to CWB in different domains as explained below.

\section{Flourishing Individuals Domain}

As local entrepreneurs strive to serve both refugee and local consumers, and provide them both with quality customer service, they opt to employ refugees as well as locals. As a result, livelihood opportunities increase for both locals and refugees. Increased livelihood opportunities in the 
community help both locals and refugees "flourish" with financial and material stability (VanderWeele 2019). Both locals and refugees enjoy the benefits of constructive engagement through marketplace interactions as the following quote from a local entrepreneur illustrates:

Ommar started to work here (furniture shop) about 3 years ago. Honestly, I hesitated to employ him when I first opened this shop because you know not everybody (Turkish people) is sympathetic to Syrians. Ommar did not know much Turkish either, even though he looked like one of us. So, I was honestly quite concerned about local reactions. But I needed a hand at the same time in order to sell to the refugees in the neighborhood. That was the reason why I opened this second shop here! Turns out it was a good decision to hire him. He has been working hard to help me reach out to the refugee community here, he knows how to interact best with fellow Syrians, and most importantly he knows Arabic! He managed to promote my shop in the refugee community more than I imagined. Thank God, business is good. I may even need to hire one more Syrian due to increasing volume of refugee customers. (Mustafa, local entrepreneur)

Employing a refugee in his new venture proved to be a wise decision for Mustafa. With the help of Ommar, Mustafa could attract refugee customers as he had initially planned. Mustafa's comments show that he feels he is flourishing as his business grows while working through Ommar to reach out to other Syrians.

\section{Good Relationships Domain}

Our data collection allowed us to see both sides of good relationships. In the example above, it is not only Mustafa who enjoyed the positive outcomes of employing a refugee. Ommar's comments below show the mental and physical health improvements he experienced after starting to work at this local business:

I feel like I am important now. I do something appreciated. It was so difficult at the beginning when I had to stay home for a while. I felt so useless. I had this never ending headache all day. I didn't know what to do. I had two little kids. You feel so hopeless when you don't know how to support them. Then I heard that Mustafa was looking for someone speaking Arabic for his new shop. Thank God, he hired me! For the first time, I felt as if I am not a refugee here. I had a regular job that I could do well. It was not paying too much but I felt like I was doing something you know. And I could feed my family, too. Kamer (daughter) will start primary school next year, and I hope I can provide her with a good education if I keep working hard. Such a peace of mind to know that you can take care of your family. (Ommar, refugee employee)

Working at a place where he is needed improves Ommar's overall mood, and helps him recover from some previous negative feelings due to displacement and unemployment. Increased livelihood opportunities seem to bring hope to Ommar's life, and contribute to both his and his family's well-being. Both Mustafa and Ommar are flourishing individually but also enjoying good relationships as a result of their trust and working together in business. Mutual economic gain in the marketplace decreases local resentment toward refugees, and contributes to social cohesion.

\section{Proficient Leadership Domain}

Those in positions of power who care about the well-being of everyone in a community can help that community thrive (VanderWeele 2019). In the context of a refugee-hosting community, local businesses have the potential to lead by example, and inspire others in the community in terms of good relationships with refugees through consistent care and quality customer service.

Local and refugee entrepreneurs can also assume the role of leadership in their respective communities in an attempt to show that everybody wins when locals and refugees work together. Successful local-refugee partnerships, for instance, set good examples for others, and encourage further entrepreneurial activity between locals and refugees that could benefit the whole society as the following quote from a local entrepreneur illustrates:

When I first shared my idea of partnering with a Syrian, people thought I was crazy. But I believed I could develop my business that way. Some mutual friends introduced me to Hassan, who was a furniture dealer in Damascus before war. He had recently come to Turkey from UAE. He was well-respected in the refugee community, had some Turkish ties, and seemed to be a competent businessman. I opened up my thoughts on doing export business together. He was positive, too. We ventured into this small export company together about 2 years ago, and now doing business with some Arabic countries across the region. Hassan's connections help a lot. He mostly deals with our export operations and I take care of local and legal procedures. We thrive together by helping each other. Everybody who sees how far we have come together gets really surprised. My brother who was really mad at me because I partnered with a "refugee" now works with us! (Ali, local entrepreneur)

Ali assumes the role of leadership by providing his community with a successful example that proves many locals wrong about their initial suspicions in partnering with a refugee. He comments that other people who see what they have accomplished together are surprised. Some even started to work with Ali and Hassan despite their initial reactions to this partnership.

\section{Healthy Practices Domain}

A well-functioning community relies on practices that help handle conflicts and disputes in order to allow relationships to develop, and strengthen (VanderWeele 2019). Local entrepreneurs can pave the way to improved CWB by adopting improved businesses practices in the marketplace.

The following quote illustrates how well received a local business' pricing policy is in the refugee community:

I have a favorite Turkish store where I always shop. They don't sell something at a price to Turks, and at another to Syrians like many 
other Turks do. They have "price tags" on each and every item in the entire store. We know the price of everything before going to the cash register, and we also know everybody is charged the same price. They don't take advantage of us due to our lack of Turkish, you know. Or they don't charge us more just because we are Syrians... You pay what you see on the price tag. Everything is fair and straightforward in that store. So, I know I can trust them. (Fatma, refugee consumer)

The transparency afforded by a simple price tag on each item eases the minds of refugees and helps a local business succeed in a market highly populated with refugees. As a matter of fact, such practices improve shopping standards for the entire community including locals as Ayşe, a local consumer, tells about her satisfaction with seeing price tags at the same local store that Fatma mentioned above:

We just had to take whatever price they told us before. OK, you could bargain but you never knew if they told the same price to everyone. I feel much better when I see price tags here. It is like in supermarkets now. You don't have to ask the price of everything any more. This is better. You also know what you will pay and you can make better budgeting, too. (Ayşe, local consumer)

\section{Satisfying Community Domain}

A community should welcome all its members, and provide them with a sense of belonging for the sustainability of its well-being (VanderWeele 2019). This is even truer in refugeehosting communities, which include many members who need to integrate in order to survive and thrive. Local entrepreneurs can help refugees integrate through marketplace interactions.

Interestingly, some refugees seem to utilize marketplace interactions to heal their social wounds. They try to compensate for their unpleasant experiences with the local community by creating some pleasant ones at safe places such as local businesses with a refugee-friendly attitude as the following quote explains:

In some Turkish shops, we don't feel like we are secondary, less important than Turkish customers. Some Turkish shopkeepers even show sympathy to our kids unlike those others who insult us when we go shopping to their stores with the kids. They sometimes give the kids some treats and stuff when we go there. That makes the kids really happy. When they are happy, we are happy you know. They are already bullied much at a school, and I want them to see they are lovable. So, I always take Farid (son) with me when I go to that Turkish shop. (Nur, refugee consumer)

Nur's conscious effort to make her son feel good about himself with a positive shopping experience at a local business is noteworthy for all stakeholders who care about creating a satisfying community.

\section{Strong Mission Domain}

A community thrives only if its members can accomplish more together than what everybody could individually achieve
(VanderWeele 2019). During our data collection in these refugee-hosting communities, we only saw the beginning of a strong mission where people feel they are working together to make the world a better place. Local-refugee partnerships and cross-employment between locals and refugees, for instance, cultivate a mission for "mutual gain" in the community as the following quote of a local business owner exemplifies:

We are in this together. They needed jobs and I needed labor. This little industrial district is full of various manufacturers, all of which used to suffer from picky workers. Turkish people do not want to do dirty work anymore. So, we cannot find enough people to work at some manufacturing facilities. You know what; honestly, we (local business owners) could not have survived if Syrians hadn't come. Seriously! They happened to be a life saver for many manufacturers like us. We are together in this. They make a living here, feed their families, and we keep our businesses running thanks to their labor. (Nusret, local business owner)

We are optimistic that as trust in local businesses grows, and entrepreneurship increases, a strong mission that will further CWB will develop.

\section{Discussion}

Marketplace trust has the potential to facilitate community well-being. This research has shown how institutional trust across cultural boundaries can encourage entrepreneurship, and lead to some positive outcomes for a diverse community. Our research in this tense refugee context confirms the importance of institutional trust in QOL studies. In the face of extreme prejudice and uncertainty, institutional trust opens the door for increased entrepreneurial activity by both locals and refugees. As the marketplace connections strengthen, CWB is more attainable for all.

Our emerging model (Figure 1) provides a look at how (dis)trust can lead to entrepreneurship and QOL. Our findings explicate multiple paths through which (dis)trust in local businesses contributes to some entrepreneurial endeavors among locals and/or refugees. Path 1 shows that QOL of refugees may increase as a result of refugee entrepreneurship due to distrust in local businesses. However, QOL may not increase for local business owners. Path 2 and path 3, on the other hand, show that QOL of both refugees and locals can improve through increased entrepreneurship of refugees and locals when refugees trust local businesses. Of the three paths, path 2 and path 3 contribute to CWB encompassing both locals and refugees, while path 1 contributes to the well-being of refugees only.

It is important to note that "distrust" was initially the main driver of entrepreneurship among refugees, and thus path 1 came forward in the earlier period of our research, while path 2 and path 3 gained more prominence later as business-savvy locals tried to capitalize on refugee networks and trusting relationships with them.

Table 1 lists different factors of (dis)trust in local businesses, which lead to increased entrepreneurship and 
subsequent well-being outcomes for locals and/or refugees. The table summarizes various ways through which locals and/or refugees engage in entrepreneurial activities. It also summarizes how QOL of refugees and/or locals improves as a result of increased entrepreneurship in both communities.

There are three main points around which we will discuss our intended contribution. First, we study trust in a diverse and risky subsistence context. Second, we have developed the connection between trust and entrepreneurship. Third, we consider the macro-level well-being outcomes. For each area, we discuss how we hope our work builds on and contributes to the relevant literature as well as corresponding policy recommendations.

Our first intended contribution is in studying the critical topic of trust in a high-risk and diverse subsistence context. The context we have explored is the millions of Syrian refugees living across Turkey. Trust is at a premium in the face of massive uncertainty (Ndubisi and Natarajan 2016) about the willingness of Turkish communities to receive such an influx of migrants and see them extend their stay beyond being temporary "guests." Trust is naturally easier to come by within a single family or a homogeneous community. However, institutional and system-level trust are difficult to achieve when this requires trust that spans boundaries. Even though there may be sharp divisions over the macro-level forces and leadership decisions that led to the influx of migrants, our research has shown that institutional trust can still develop, and benefit the community at large including both locals and refugees.

Distrust in this refugee context is not simply about two individuals or between institutions, but rather the suspicion between large people groups in a dynamic macro environment. Especially in a subsistence context, there is an absence of the dichotomy between firms and customers, and instead an interconnected group of actors that are co-creating value (Vargo and Lusch 2011).

Macromarketing is founded on the interdependence of elements in the marketing system (Kilbourne 2004; Mittelstaedt, Kilbourne, and Mittelstaedt 2006). This research expands the range of interdependence to more diverse elements across a broader community. Although full shared commitment (Watson and Ekici 2017), which also has elements of the "strong mission" (VanderWeele 2019), may be less attainable amongst more diverse actors beyond the links of a single network, our research has shown that institutional trust can encourage entrepreneurial activity, and improve CWB.

Our research corroborates the literature on the value of social networks and social capital in subsistence contexts (Viswanathan, Sridharan, and Ritchie 2010). According to this literature, better-connected entities enjoy higher returns (Burt 2000). We have shown ways that social capital can develop as a result of trusted relationships between refugees and local business owners in the marketplace, and that increased social capital contributes to increased entrepreneurship in the entire community. Social media emerged from our findings as a tool that accelerates the speed of word traveling between refugees. If one local store owner is found to be trustworthy, more refugees will support this shop owner, and even the entrepreneurial efforts of others in this person's social network, as we shared in our findings.

Our second intended contribution is in showing the link between institutional trust and entrepreneurship. Previous research has shown the importance of trust in subsistence marketplaces. Viswanathan, Sridharan, and Ritchie (2010) showed that embeddedness in social networks in subsistence marketplaces increases individuals' engagement in entrepreneurial activities in order to overcome vulnerabilities related to poverty. Our study agrees with Samli (2008) that entrepreneurship is a way to improve economic conditions from the bottom-up, and improve QOL. We build on his work to show the importance of institutional trust across cultural boundaries. If refugees trust the businesses owned by locals, it accelerates both local and refugee entrepreneurship, leading to improved QOL in both groups and overall CWB. We agree with the "community-oriented and entrepreneurially-driven perspective of alleviating poverty in locally sustainable ways" (Viswanathan and Sridharan 2009, p. 4).

Ekici and Peterson (2009) demonstrated that people below the poverty line who have greater trust in market-related institutions report higher QOL. Our research builds on how (dis)trust in businesses might lead to entrepreneurship, which in turn influences CWB. We consider trust and social networks across a clear cleavage between refugees and their local hosts, and show how it generates entrepreneurship. A shared mission (VanderWeele 2019) of survival can help people engage in exchange relationships.

Exchange transactions between local businesses and the impoverished refugees based on values such as authentic engagement and co-creation of value can lead to long-term relationships, customer empowerment, sustainable business initiatives, and fairer marketplaces (Santos and Laczniak 2009). We build on this work by showing that the empowered actors within the impoverished market sector can start their own businesses, which contribute to a broader CWB. We explicitly emphasize the importance of institutional trust in entrepreneurial activity accelerating across boundaries. Our research also provides empirical evidence of how authentic engagement can lead to fairer marketplaces (Santos and Laczniak 2009). We showed how acts of kindness like greeting a child or closing a shop to mourn the death of a Syrian employee lead to trust and increased patronage of local businesses across ethnic boundaries.

From a policy perspective, we encourage efforts to facilitate business partnerships across the heterogeneous elements in a community. As business leaders become financially interdependent, the broader groups that they represent may see that their QOL can be improved rather than just infringed upon by the other. Another policy priority could be equality in the marketplace. The laws and incentives should create a level playing field for the local and refugee entrepreneurs. In our data collection in the community, we saw how resentment can build if refugees do not pay the taxes required of local businesses and are not inspected like locals. Similarly, if refugee entrepreneurs 
feel the Turkish businesses are being protected through red tape that stymies new entrants, they may feel slighted. When the market feels the most equitable and free is when entrepreneurs are incentivized to do their innovative work. Whatever incentives and programs are offered, they should be offered equally. Distrust is exacerbated if one group feels that another is favored.

Third, we aim to show the link between institutional trust and macro-level well-being. One of our intended contributions is to bring the domains of $\mathrm{CWB}$ to bear on the research on trust and distrust. The larger CWB framework of VanderWeele (2019) helps us move away from a narrower focus on $\mathrm{QOL}$, to seeing that $\mathrm{CWB}$ requires trust to be built between groups. In our findings, we presented evidence of how trust-driven entrepreneurship is leading to flourishing individuals, good relationships, proficient leadership, healthy practices, a satisfying community, and a strong mission - the domains of CWB. Our analysis is at a higher level of considering these domains between diverse groups. Sirgy (2011) reminds us that a good society is more than just the sum of the happiness of the individual citizens that compose it. We presented evidence of how, for example, shopkeepers treating refugees well encourages refugees to take their kids shopping, and leads to a sense of belonging in a satisfying community. Hiring Syrian employees improves the QOL of not just a single refugee, but the local business owner, both of their families, and their entire community. As one local business owner said, "We are in this together... Honestly, we could not have survived if Syrians hadn't come." We acknowledge the complexity of CWB by showing that some local business owners can be adversely affected by the disruption of entrepreneurship.

We maintain that policies need to be oriented toward overall CWB, and not narrower goals such as the QOL of refugees. Programs that encourage diverse groups to consider that more can be accomplished by working together will be more enduring. Financial well-being of both refugees and locals is essential for the sustainability of CWB. If there is a thriving marketplace with exchanges between the refugee and host businesses, and consumers, well-being can continue to improve.

\section{Conclusion, Limitations, and Research Extension}

There are several limitations to this study. We did a thorough research with dozens of diverse informants across multiple cities, but our research is still rooted within a particular country with its unique complexities in how refugees are received. We hope future studies can be done in diverse contexts, such as among more affluent migrant communities.

Although we believe our qualitative methodology was valuable in exploring trust and distrust among refugees in a local context, we did not precisely measure the constructs used. In future research the constructs such as the "trust in local business" or "entrepreneurial activity" could be measured, and the emerging model (Figure 1) tested.
We opted to focus on the (dis)trust of the refugees who have less of a voice, but future research could start with the perspective of the local community. We intentionally emphasized the perspective of marginalized refugees, but the complexity on the local community side may be revisited. Future research could also delve more into the negative outcomes of entrepreneurial activity in a community. As we touched upon in a few quotations from a local business owner and consumers, entrepreneurial activity is disruptive to pricing and existing business relationships. Drug and human trafficking are more extreme examples of dark sides of enterprising people struggling for survival. Indeed, during the collection of data, there was veiled mention of such illegal activities, but we took their advice to stay clear.

Despite its limitations, our research aims to contribute to the body of scholarly work on improving outcomes in subsistence marketplaces. We hope that our research has shown the importance of trust across cultural boundaries in generating entrepreneurship and CWB. With more movement of people across borders than at any time before (UNHCR 2019), the issue of trust in complex marketplaces will remain demanding. Movements of people, including refugees, is likely to remain one of the most pressing macro issues of our time. In an increasingly diverse and networked world, we believe that the understanding of how markets, marketing, and society (Dixon 2002) can best contribute to improved well-being throughout the global economic pyramid is more pressing than ever.

\section{Declaration of Conflicting Interests}

The author(s) declared no potential conflicts of interest with respect to the research, authorship, and/or publication of this article.

\section{Funding}

The author(s) disclosed receipt of the following financial support for the research, authorship, and/or publication of this article: This research is a part of Zeynep Baktir's PhD Thesis at Bilkent University, Faculty of Business Administration. She received research support from the faculty for her site visits.

\section{ORCID iDs}

Zeynep Baktir (D) https://orcid.org/0000-0002-2768-5578

Forrest Watson (D) https://orcid.org/0000-0002-8820-1434

\section{References}

Anderson, Alistair R. and Sarah L. Jack (2002), "The Articulation of Social Capital in Entrepreneurial Networks: A Glue or A Lubricant?" Entrepreneurship \& Regional Development, 14 (3), 193-210.

Building Markets (2017), “Another Side to the Story," (accessed October 31, 2019), [available at https://buildingmarkets.org/sites/ default/files/pdm_reports/another_side_to_the_story_a_market_ assessment_of_syrian_smes_in_turkey.pdf]

Burt, Ronald S. (2000), “The Network Structure of Social Capital,”; Research in Organizational Behavior, 22, 345-423.

Burt, Ronald S. (1997), "Social Capital and Network Content," Social Networks, 19 (4), 355-73. 
Callamard, Agnes (1994), "Refugees and Local Hosts: A Study of the Trading Interactions between Mozambican Refugees and Malawian Villagers in the District of Mwanza," Journal of Refugee Studies, 7 (1), 39-62.

Chandler, Jennifer and Stephen L. Vargo (2011), "Contextualization: Network Intersections, Value-in-Context, and the Co-creation of Markets," Marketing Theory, 11 (1), 35-49.

DGMM (Directorate General of Migration Management), (2019), "Temporary Protection", (accessed October 30, 2019), [available at https://en.goc.gov.tr/temporary-protection27].

Dixon, Donald F. (2002), "Emerging Macromarketing Concepts: from Socrates to Alfred Marshall," Journal of Business Research, 55 (2), 87-95.

Earle, Timothy C. and George Cvetkovich (1995), Social Trust: Toward a Cosmopolitan Society. Westport, CT: Greenwood Publishing Group.

Ekici, A. and Mark Peterson (2009), "The Unique Relationship between Quality of Life and Consumer Trust in Market-related Institutions among Financially Constrained Consumers in a Developing Country," Journal of Public Policy \& Marketing, 28 (1), 56-70.

Fligstein, Neil and Luke Dauter L. (2007), "The Sociology of Markets," Annual Review of Sociology, 33, 105-28.

Freitag, Markus (2003), "Social Capital in (Dis)Similar Democracies: The Development of Generalized Trust in Japan and Switzerland," Comparative Political Studies, 36 (8), 936-66.

Fukuyama, Francis (1995), Trust: The Social Virtues and the Creation of Prosperity (Vol. 99). New York: Free press.

Hetherington, Marc J. (1998), "The Political Relevance of Political Trust," American Political Science Review, 92 (4), 791-808.

Hudson, John (2006), "Institutional Trust and Subjective Well-being across the EU," Kyklos, 59 (1), 43-62.

Inglehart, Ronald (1997), Modernization and Postmodernization. Princeton: Princeton University Press.

Inglehart, Ronald and Jacques-Rene Rabier (1986), “Aspirations Adapt to Situations - But Why are the Belgians so much Happier than the French? A Cross-cultural Analysis of the Subjective Quality of Life," in Research on the Quality of Life, F. M. Andrews, ed. Ann Arbor: Institute for Social Research University of Michigan.

Kilbourne, William E. (2004),“Globalization and development: An Expanded Macromarketing View," Journal of Macromarketing, 24 (2), 122-35.

Mason, Jennifer (2002), Qualitative Researching. London: Sage.

Meyer, Sarah R., Elizabeth Meyer, Clare Bangirana C., Patrick Onyango Mangen, and Lindsay Stark (2019), "Protection and Well-being of Adolescent Refugees in the Context of a Humanitarian Crisis: Perceptions from South Sudanese Refugees in Uganda," Social Science \& Medicine, 221, 79-86.

Michalos, Alex C. (1990), "The Impact of Trust on Business, International Security and the Quality of Life," Journal of Business Ethics, 9 (8), 619-38.

Miles, Matthew B. (1994) Miles and Huberman Chapter 2. In: Qualitative Data Analysis. London, England: Sage, 50-72.
Mishler, William and Richard Rose (2001), "What are the Origins of Political Trust? Testing Institutional and Cultural Theories in Post-communist Societies," Comparative Political Studies, 34 (1), 30-62.

Mittelstaedt, John D., William E. Kilbourne, and Robert A. Mittelstaedt (2006), "Macromarketing as Agorology: Macromarketing Theory and the Study of the Agora," Journal of Macromarketing, 26 (2), 131-42.

Ndubisi, Nelson Oly and Rajan Nataraajan (2016), "Marketing Relationships in the New Millennium B2B Sector," Psychology \& Marketing, 33 (4), 227-31.

North, Douglas C. (1990), Institutions, Institutional Change, and Economic Performance. New York: Cambridge University Press.

Portes, Alejandro and Julia Sensenbrenner (1993), "Embeddedness and Immigration: Notes on the Social Determinants of Economic Action," American Journal of Sociology, 98 (6), 1320-50.

Prahalad, Coimbatore K. (2009), The Fortune at the Bottom of the Pyramid, revised and updated 5th anniversary edition: Eradicating Poverty through Profits. Upper Saddle River: FT Press.

Putnam, R. D. (2000), "Bowling Alone: America's Declining Social Capital," in Culture and Politics. New York: Palgrave Macmillan, 223-34.

Putnam, Robert (1993), “The Prosperous Community: Social Capital and Public Life," The American Prospect, 13, 35-42.

Rosa, A. José and Madhubalan Viswanathan, ed. (2007), Product and Market Development for Subsistence Marketplaces. Bingley: Emerald Group Publishing Limited.

Ruth, Julie. A. and Rachel Hsiung (2007), “A Family Systems Interpretation of How Subsistence Consumers Manage: The Case of South Africa." in Product and Market Development for Subsistence Marketplaces. Bingley: Emerald Group Publishing Limited, 59-87.

Samli, A. Coskun (2008), "Entrepreneurship, Economic Development and Quality of Life in Third-world Countries," Applied Research in Quality of Life, 3 (3), 203-13.

Santos, Nicholas J. C. and Gene R. Laczniak (2009), "Marketing to the Poor: An Integrative Justice Model for Engaging Impoverished Market Segments," Journal of Public Policy and Marketing, 28 (1), 3-15.

Sirgy, M. Joseph (2011), "Societal QOL is More than the Sum of QOL of Individuals: The Whole is Greater than the Sum of the Parts," Applied Research in Quality of Life, 6 (3): 329-34.

Sirgy, M. Joseph, Alex C. Michalos, Abbott L. Ferriss, Richard A. Easterlin, Donald Patrick, and William Pavot (2006), "The Quality-of-Life (QOL) Research Movement: Past, Present, and Future," Social Indicators Research, 76 (3): 343-466.

Sirgy, M. Joseph, Robin N. Widgery, Dong-Jin Lee, and B. Yu Grace (2010), "Developing a Measure of Community Well-Being Based on Perceptions of Impact in Various Life Domains," Social Indicators Research, 96 (2): 295-311.

Sung, HeeKyung and Rhonda G. Phillips (2018), "Indicators and Community Well-being: Exploring a Relational Framework," International Journal of Community Well-Being, 1 (1), 63-79.

Sztompka, Piotr (1999), Trust: A Sociological Theory. Cambridge: Cambridge University Press. 
TEPAV (The Economic Research Foundation of Turkey) (2018), "Syrian Entrepreneurship and Refugee Start-ups in Turkey: Leveraging the Turkish Experience," (accessed October 30, 2019), [available at https://www.tepav.org.tr/en/yayin/s/1430]

TUIK (Turkish Statistical Institute) (2019), "Population Statistics," (accessed October 31, 2019), [available at http://www.turkstat. gov.tr]

UNHCR (United Nations High Commissioner for Refugees) (2019), "Global Trends: Forced Displacement in 2018," (accessed October 30, 2019), [available at https://www.unhcr.org/statistics/ unhcrstats/5d08d7ee7/unhcr-global-trends-2018.html]

Uslaner, Eric M. (2002), The Moral Foundations of Trust. Cambridge: Cambridge University Press.

VanderWeele, Tyler J. (2019), "Measures of Community Well-Being: a Template," International Journal of Community Well-Being, 2, 253-75.

Vargo, Stephen L. and Robert F. Lusch (2011), "It's all B2B and Beyond ... . Toward a Systems Perspective of the Market," Industrial Marketing Management, 40 (2) 181-87.

Viswanathan, M. (2017), "What the Subsistence Marketplaces Stream is Really About: Beginning with Micro-level Understanding and Being Bottom-up," Journal of Marketing Management, 33 (17-18), 1570-84.

Viswanathan, Madhu, José Antonio Rosa, and Julie Ruth (2010), "Exchanges in Marketing Systems: The Case of Subsistence Consumer-Merchants in Chennai, India," Journal of Marketing, 74 (3), $1-17$.

Viswanathan, Madhu, Raj Echambadi, Srinivas Venugopal, and Srinivas Sridharan (2014), "Subsistence Entrepreneurship, Value Creation, and Community Exchange Systems: A Social Capital Explanation," Journal of Macromarketing, 34 (2), 213-26.

Viswanathan, Madhu, Srinivas Sridharan, and Robin Ritchie (2010), "Understanding Consumption and Entrepreneurship in Subsistence Marketplaces,"Journal of Business Research, 63 (6), 570-81.

Viswanathan, Madhubalan (2007), "Understanding Product and Market Interactions in Subsistence Marketplaces: A Study in South India," in Product and Market Development for Subsistence Marketplaces. Bingley: Emerald Group Publishing Limited, 21-57.

Viswanathan, Madhubalan and Srinivas Sridharan (2009), "From Subsistence Marketplaces to Sustainable Marketplaces: A Bottom-up
Perspective on the Role of Business in Poverty Alleviation," Ivey Business Journal, 73 (2), 1-15.

Viswanathan, Madhubalan and Srinivas Venugopal (2015), "Subsistence Marketplaces: Looking Back, Looking Forward," Journal of Public Policy \& Marketing, 34 (2), 228-34.

Viswanathan, Madhubalan, Jose Antonio Rosa, and James Edwin Harris (2005), "Decision Making and Coping of Functionally Illiterate Consumers and Some Implications for Marketing Management," Journal of Marketing, 69 (1), 15-31.

Viswanathan, Madhubalan, Srinivas Sridharan, Robin Ritchie, Srinivas Venugopal, and Kiju Jung (2012), "Marketing Interactions in Subsistence Marketplaces: A Bottom-up Approach to Designing Public Policy," Journal of Public Policy \& Marketing, 31 (2), 159-77.

Watson, Forrest and Ahmet Ekici (2017), "Well-being in Alternative Economies: The Role of Shared Commitments in the Context of a Spatially-extended Alternative Food Network," Journal of Macromarketing, 37 (2), 206-16.

Whitaker, Beth E. (2002), "Refugees in Western Tanzania: The Distribution of Burdens and Benefits among Local Hosts," Journal of Refugee Studies, 15 (4), 339-58.

Wilkie, William L. and Elizabeth S. Moore (1999), "Marketing's Contributions to Society," Journal of Marketing, 63 (4_suppl 1), 198-218.

Woolcock, Michael (1998), "Social Capital and Economic Development: Toward a Theoretical Synthesis and Policy Framework," Theory and Society, 27 (2), 151-208.

\section{Author Biographies}

Zeynep Baktir is completing her PhD in Marketing at Bilkent University in Ankara, Turkey. She received her BS in Business Administration from Bilkent University, and her MBA from the University of Texas, Dallas. Her research interests include social and cultural dimensions of consumption, consumer well-being, vulnerable groups, macromarketing, transformative consumer research, and social marketing.

Forrest Watson ( $\mathrm{PhD}$, Bilkent University) is an assistant professor of Marketing at Middle East Technical University. His research interests include quality of life, macromarketing, transformative consumer research, and social marketing. 